INDEPENDENT JOURNAL OF MANAGEMENT \& PRODUCTION (IJM\&P)

http://www.ijmp.jor.br

v. 12, n. 2, March-April 2021

ISSN: 2236-269X

DOI: $10.14807 /$ ijmp.v12i2.1331

\title{
BUSINESS PROCESS MANAGEMENT (BPM) APPLICATION THROUGH STRATEGY, INDICATORS AND OPERATIONS MODEL (MEIO): A HEALTH SERVICE COMPANY CASE
}

\author{
Carolina Melecardi Zani \\ Universidade Federal do Rio Grande do Sul, Brazil \\ E-mail: zani.carol@gmail.com \\ Mirele Marques Borges \\ Universidade Federal do Rio Grande do Sul, Brazil \\ E-mail: mirelem.borges@gmail.com \\ Ana Júlia Brum Severo \\ Universidade Federal do Rio Grande do Sul, Brazil \\ E-mail: anajuliabrumsevero@gmail.com \\ Eduardo Rocha Garcia \\ Universidade Federal do Rio Grande do Sul, Brazil \\ E-mail:erg.engst@gmail.com \\ Cláudio José Miller \\ Universidade Federal do Rio Grande do Sul, Brazil \\ E-mail:cmuller@producao.ufrgs.br \\ Submission: 4/6/2020 \\ Revision: 4/21/2020 \\ Accept: 6/10/2020
}

\section{ABSTRACT}

Business Process Management (BPM) is an approach to analyze and improve main activities of a company continuously. It seeks consistent results aligned with the strategic objectives. There are several approaches to the application of BPM, which focus on specific aspects of the company, not meeting all their needs. The Strategy, Indicators and Operations Model (MEIO), developed by Müller (2003), compiles the fundamental points of each isolated approach, creating a single model. The objective of this work is to provide a step-by-step application of the BPM aspects of MEIO in a practical case: a reference company that provides health services. Also, it provides a framework for organizing and connecting the various components of a product or service to its value chain. Through MEIO, a general analyze of the Company under study was made and the process "payment of invoices from providers" was detailed. Improvements were suggested based on a deeper investigation of the activities involved. 
DOI: 10.14807/ijmp.v12i2.1331

The results include: (i) creation of rules engine to validate the procedures to be launched according to coverage, shortage, and contract; (ii) receiving procedure and cost audits separately and; (iii) digitalization and automatization of repetitive and manual activities.

Keywords: Business Process Management; BPM; Strategy, Indicators and Operations Model; MEIO

\section{INTRODUCTION}

The current market is increasingly competitive, forcing companies to adapt to a globalized environment, with significant changes in business paradigms, such as uncertainty and changeability (Cho, 2014). This economic environment has led to a growing interest by companies in improving organizational business processes and performance, and, consequently, enhance their operational efficiency and reduce costs (Mccormack et al., In Press, Ranganathan \& Dhaliwal, 2001). Business Process Management (BPM) has over the last years appeared as a process-oriented solution that work well both towards human understanding and execution (Trætteberg \& Krogstie, 2008).

BPM is an approach to management process with focus on modeling, documenting, simulating, automating, measuring, monitoring, and improving processes to achieve consistent results in line with strategic objectives aspects of the organization (Murlick, 2014). In other words, BPM is the effort in an organization to continuously analyze and improve fundamental activities such as manufacturing, marketing, communications, and other essential elements of the company's operations (Zairi, 1997).

Also, BPM considers the organization as a complete and dynamically coordinated set of logically related activities or tasks that must be performed to add value to people (customers, employees, shareholders, and society), justifying the existence and survival of an organization (Guha \& Kettinger, 1993; Burlton, 2001; Strnadl, 2006; De Sordi, 2012). Once well-executed, BPM guarantees continuous improvement of operational performance, transforming strategies into actions, which result in products or services capable of meeting the needs of the main stakeholders (Burlton, 2001; De Sordi, 2012). In addition to being a technique to achieve improvement, BPM is a means to spread awareness throughout the organization focusing on processes improvement (Lee \& Dale, 1998).

In this context, the adequacy between an organization and its strategy, structure, processes, technology, and environment has been a basis for the construction and research of theories approaching BPM (Kanellis et al., 1999). As an example, two of those theories are the 
INDEPENDENT JOURNAL OF MANAGEMENT \& PRODUCTION (IJM\&P)

http://www.ijmp.jor.br

v. 12, n. 2, March-April 2021

ISSN: 2236-269X

DOI: 10.14807/ijmp.v12i2.1331

Intellectual Capital (Stewart, 1998; Edvinsson \& Malone, 1998) and the Net Promoter Score (Reichheld, 2003).

The first is a label to identify intangible assets within an organization and to break them down into meaningful sections (Young, 2012), while the latter is a way to measure customer satisfaction and loyalty, meaning better finances (Markey et al., 2007). These theories attend part of the company's needs, as financial and economic aspects, and neglect others, as customer retention and employee engagement (Porter, 1996). To deal with this challenge, executives often go through a period of recycling their main business processes, commonly based on departmentalization, operationalization, and management of a specific area, or of each area separately, not attending the whole and not having a systemic view of business (Torres, 2015).

Since existing isolated models do not seem to cover all BPM aspects of companies, one method to perform it is through the Strategy, Indicators and Operations Model (MEIO), developed by Müller (2003). This method was built based on several authors (Harrington, 1993; Rummler \& Brache, 1994; Simpson et al. 1999; Lee \& Dale, 1998), and compiles the fundamental aspects of these studies. MEIO advantages, when compared to conventional models, is that it complements the weaknesses of one approach with the strengths of another.

Yet, it offers different points of view and ideas to everyday issues of BPM. Thus, MEIO comprises five steps: (i) overview; (ii) processes hierarchy; (iii) team definition; (iv) processes prioritization and; (v) details. This view is in agreement with Albuquerque and Rocha (2006), who report that the implementation of BPM methodology must be carried out in phases. To this end, Müller (2003) establishes the process mapping as the primary tool to understand the processes and visualize the activities in various functions of the organization, allowing opportunities for simplification and improvement.

Several empirical studies indicate that there is a positive correlation between process management and business success (Mccormack \& Johnson, 2001; Mccormack et al., In Press \& Skerlavaj et al., 2007). While BPM focus on improving fundamental activities of a company, MEIO appears as an alternative to consolidate it, mainly by joining different performance analysis. This work applies the BPM aspects of MEIO to a significant health service company.

The study follows all five stages proposed by Müller (2003), improved by the processes map and the appropriate flowcharts. It provides a step-by-step application of MEIO to a health service company and a framework for organizing and connecting the various components of a product or service to its value chain. Additionally, this work guides future managers in the process analysis and suggestions for improvements. It shows ways to redesign the processes, 
INDEPENDENT JOURNAL OF MANAGEMENT \& PRODUCTION (IJM\&P)

http://www.ijmp.jor.br

v. 12, n. 2, March-April 2021

ISSN: 2236-269X

DOI: 10.14807/ijmp.v12i2.1331

making it agile and synchronized with corporate strategies, generating sustainable competitive advantages.

\section{HISTORICAL BACKGROUND OF BPM AND APPLICATIONS OF MEIO}

The theme of Process Management has been approached over the last decades from a perspective of linear and isolated to a more integrated and systemic view, assisting in the documentation, analysis, and improvement of business processes (Schmiedel et al., 2020). The concepts of "process" started to be part of the daily life of organizations, more specifically in the production sector, with the approaches of Manufacturing Resources Planning (MRP II) and factory layout (Aghabaghery et al., 2020). In this context, structures of organizations based on limited processes (i.e., departmentalization) were common, originally coming from Taylorism (1911), which introduced several concepts, such as efficiency, specialization, and process measurement (De Sordi, 2012).

In Taylorism, the processes were rigid and well detailed, leaving employees little freedom. With the development of a more competitive market, companies were forced to take initiatives that highlight them through improvements in productivity and quality of the product or service. Thus, measurements and indicators became part of everyday life, and practices called "quality" were disseminated (De Sordi, 2012; Brocke et al., 2014; Vom Brock \& Rosemann, 2013). Some of them are: Total Quality Management (TQM), Total Quality Control (TQC), Continuous Quality Improvement (CQI) (Elzinga et al., 1995).

In the late 1980s, two main authors disseminated the concepts of process management: Thomas Davenport and Michael Hammer. They focus on improving the processes that generate these products and services, and not just on the products themselves (Elzinga et al., 1995). Since then, there has been a contrast between traditional companies, focused on what happens within the company itself and those organized by business processes, which prioritize the end customer, cooperation between teams, and individual responsibility (Dumas et al., 2013).

In this way, the orientation by processes was disseminated in opposition to the functional vision of the organizations. This new vision was present in several popular models in the 1990s: European Foundation for Quality Management (EFQM), Malcolm Baldrige National Quality Award (MBNQA), ISO 9000, and Reengineering, in addition to TQM itself (Lee \& Dale, 1998).

Over the past 20 years, interest in the Process Management area has grown and consolidated the concept of BPM. Initially defined as a technology-oriented system, it became a management practice and, currently, a discipline that deals with both organizational and 
DOI: 10.14807/ijmp.v12i2.1331

technological aspects. Due to the importance of process management for organizations, BPM has been the subject of several studies involving managers, users, analysts, consultants, service providers/suppliers, and academics (Vom Brocke \& Rosemann, 2013). Therefore, BPM derives from practices of the division of labor and Reengineering, incorporating aspects of Total Quality (Antonucci \& Goeke, 2011).

Iritani et al. (2015) raise the relevance of the subject when studying growing publications in the academic field. Other authors point out the advantages of implementing BPM, among them: focus on the customer, shorter response time, increased satisfaction of customers and employees, combating the departmental view, improving internal communication, standardizing activities, reducing bureaucracy, increasing the reliability of operations, improvement in people's morale, focus on results, alignment of strategic objectives with the objectives of processes and increased profits (Zairi, 1997; Detoro \& Mccabe, 1997; Harrington, 1993).

In this context, MEIO appears as a mean to active the benefits of BPM. MEIO is divided into three modules, namely: strategic planning, process management and performance evaluation. Therefore, it offers a complete solution for companies. In each of the studies where MEIO is applied, one of the modules predominates. This is a feature of MEIO: it is possible to implement only the modules needed by the company.

For example, Rafaeli and Müller (2007) point out the relationship between BPM and MEIO to establish a set of indicators to instantly alerts those responsible about events that are not expected, thereby emphasizing process management and performance evaluation. Sellitto and Walter (2006) presents a case in which the performance of an electronic equipment manufacturer was evaluated according to competition criteria, using MEIO to classify the evaluation systems and define competition criteria relevant to the case.

Other examples of application of MEIO involve operationalization of strategies, definition of strategic planning and search for a means to consolidate improvements in processes (Muller, 2003). The applications show the effectiveness of MEIO, mainly because the partial implementation of the model induces improvements in other areas. MEIO comprises five stages, which can be analyzed from the BPM point of view:

a) Overview: it is the beginning of the process, involves the creation of macro-processes, through the design of a business map, which makes possible to identify resources, inputs, outputs, influencing factors and subsystems; 
DOI: 10.14807/ijmp.v12i2.1331

b) Processes hierarchy: consists of unfolding the overview into parts, forcing managers to analyze the processes, sub-processes, and macro-process activities;

c) Team definition: clarifies the driving elements of the project, meaning, general issues and tools to be used, process owners/leaders and improvement teams;

d) Process's prioritization: it provides a broad vision to act local, involving the selection of critical processes, the establishment of preliminary objectives to guide the teams and the characterization, understood as the processes limits (where it begins, where it ends and what it includes) and;

e) details: general definitions, understanding, analysis, and improvement.

Thus, this work seeks to achieve some of the advantages provided by BPM, mentioned by Iritani et al. (2015), as shorter response time, improve internal communication, reduce bureaucracy, increase the reliability of operations and align strategic objectives with the objectives of processes. For this, the MEIO "process management" module was used as a methodology and tool.

\section{METHODOLOGY}

The research method adopted is qualitative with a case study, since it aimed at solving specific problems with deepening the understanding of an organization (Gerhardt \& Silveira, 2009). Regarding the objectives, this study is classified as an exploratory research, as it will be necessary to understand the company's daily life to achieve the improvement of ideas and discoveries (Gil, 2008). As for the procedures, the present work is characterized as action research, which presupposes the participation of the researchers in the problematic situation to be investigated (Gil, 2008).

To carry out this work, a Brazilian cooperative was chosen (Company U), located in the south of Brazil, which offers supplementary health services. The company has existed for 48 years and operates in the Metropolitan Region, Center-South and North Coast of the state. It has more than 2000 employees and 6500 cooperative doctors. The company was chosen due to (i) the fact that it is a reference organization at regional level and; (ii) authors previous contact with the management team, facilitating access to meetings and documents.

Company U sells family and business health plans, as well as complementary products and services. Its target market focuses on the corporate collective health insurance segment. This target audience comprises $87.6 \%$, formed by micro and small companies and medium and large companies (from medical offices with two doctors to large hospital centers). 
DOI: 10.14807/ijmp.v12i2.1331

The methodological procedure applied was based on the process management method developed by Müller (2003), MEIO. It was followed the five steps presented in literature review (section 2). Since MEIO implies in a global intervention, from strategy to operations, in this study, the application of MEIO is partial, focused on the BPM aspects, tangent to the other approaches.

This is a characteristic of the model: flexibility to start with one module and later add to the others. The proposed steps were applied by the authors after meetings with the management team of the company. The meetings intend to give a better understanding of the company's situation. Also, one of the authors had previously worked for that company, facilitating access. After each step, another meeting was taken to validate the developed data.

For the first step (overview) the Business Map was created, which consists of mapping, in a systematic way, the leading suppliers of the organization, the inputs, the processes developed (major company procedures, such as purchases, business execution, charges), the primary products/services delivered, and identify the buyer market. In addition, this stage also seeks to understand the general panorama of external influences, which are uncontrollable factors of the organization, such as government policies, legislation, society, culture, etc. and the company's competitions (Figure 1).

\begin{tabular}{|c|c|}
\hline \multicolumn{2}{|c|}{ External influences } \\
\hline Suppliers & Onputs \\
\hline & \\
\hline & Organization Process \\
\hline
\end{tabular}

Figure 1: Business Map Model, adapted from Müller (2003)

After understanding the environment that surrounds the company, MEIO suggests the creation of the processes general architecture of the organization (step 2, process hierarchy). This stage consists of the identification of all macro-processes (primary, support and management). The main processes are classified, detailed with the information of their limits (where it starts and where it ends), what are the resources involved, what is developed in this macro-process, what is delivered (Table 1).

In addition, the owner of the process is defined (i.e. sector with sufficient hierarchical level to understand which direction the business will take and how it will affect the process and the participants) (BPM CBOK®, 2013), the participants, the legislation relevant to the process, the necessary skills, the process indicators, and software systems used. The purpose of this comprehensive analysis, besides providing a global understanding of the company's current 
INDEPENDENT JOURNAL OF MANAGEMENT \& PRODUCTION (IJM\&P)

http://www.ijmp.jor.br

v. 12, n. 2, March-April 2021

ISSN: 2236-269X

DOI: 10.14807/ijmp.v12i2.1331

process management, is to help in prioritizing a sub-process to focus on more immediate interventions. In accordance with Jesus and Macieira (2014), the essential parts must be done first.

For Company U, the macro-process "payment of invoices from the provider" was chosen to be detailed. The choice was made based on: (i) the company's preference to focus on this macro-process, due to its importance to the cooperative and; (ii) because it is a macroprocess that involves many members and areas, thus denoting more robust opportunities for intervention.

Table 1: Characterization of main processes,

\begin{tabular}{|c|c|c|c|}
\hline \multicolumn{4}{|c|}{ Macro-process } \\
\hline Processes & Process name & Process name & {$[\ldots]$} \\
\hline Where it starts & Entity/location where it starts & & \\
\hline Entries & Documentation, information, materials & & \\
\hline What is developed & Action & & \\
\hline What is the exit & Product/Service & & \\
\hline Where it ends & Entity/location where it ends & & \\
\hline Owner & Sector with authority to make decisions & & \\
\hline Participants & Other sectors involved & & \\
\hline Legislation & Law, rules, standard procedures & & \\
\hline Skills & Necessary capacity & & \\
\hline Indicators & Visualization/direction of the process & & \\
\hline Systems & Resources, software & & \\
\hline
\end{tabular}

Source: adapted from Müller (2003)

For step 3, team definition, the relationship between the processes and the sectors was identified (Table 2). Each sector received a score between 9-3-1-0 according to their degree of involvement with the project. This score followed Müller (2003) instructions, additionally, the authors validate the punctuation during the meetings with the management team. Maximum rating (9) was attributed to the sectors responsible for the process in question, those with knowledge on the subject and with decision-making power to direct the project. Note 3 was given for the sectors classified as co-responsible, which assists in the coordination of the project secondarily. Note 1 was for sectors that only participate in the process without managerial power over it and note 0 for sectors that were not involved.

For some BPM authors (Harrington, 1993; Baldam, 2009; Oliveira, 2013), this initial mapping is the primary tool for understanding processes. Müller (2003) argues that a form of visual representation of activities, such as flowcharts and organization charts, allows the 
INDEPENDENT JOURNAL OF MANAGEMENT \& PRODUCTION (IJM\&P)

http://www.ijmp.jor.br

v. 12, n. 2, March-April 2021

ISSN: 2236-269X

DOI: 10.14807/ijmp.v12i2.1331

identification of opportunities for simplification. Thus, the flowchart was performed by the Bizagi Process Modeler software, which allows the modeling and documentation of processes using the Business Process Model and Notation (BPMN) and assisted in the visualization and interpretation of the processes (see section 4).

Table 2: Processes vs. Sectors

9 = responsible; 3 = co-responsible; 1 = participation; 0 = without participation

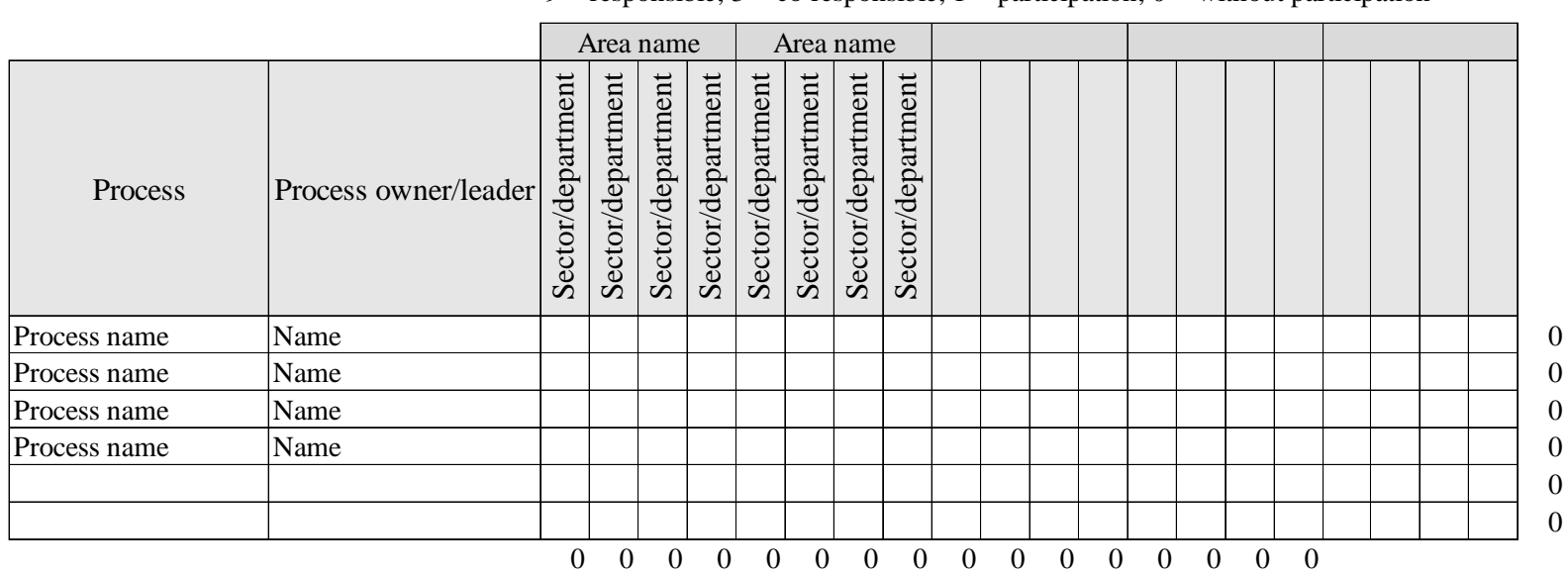

Source: adapted from Müller (2003)

Harrington (1993) proposes an understanding of the process importance, unfolding the macro-process in processes, subprocesses and activities. The subprocess's analyses correspond to step 4, process prioritization. This visualization and knowledge can be achieved by the organizational chart and the subprocess analyses table (Figure 4). Thus, an examination of the sub-processes is carried out according to MEIO guidelines. For each sub-process/activity, the added value, its relationship with quality and costs and required resources (people, equipment, etc.) was established (Table 3).

Added value corresponds to subjective issues related to value (utility, aesthetic, prestige, brand) that is often as important as economic value (Hansen, 1995). There are three types of "added value” activities in a company: (i) added real value activities (ARV), adds to the customer; (ii) added business value activities (ABV), necessary for the process and; (iii) no added value (NAV), unnecessary for the process, resulting in useless disposal of resources with unnecessary costs to the product/service (these must be eliminated) (Müller, 2003). This step aims to improve the understanding of the characteristics of the process for further improvement and standardization through analyzes of quality, time, costs, and added value. 
Table 3: Subprocess analysis

\begin{tabular}{|c|c|c|c|c|c|c|c|c|c|c|c|c|}
\hline \multirow[b]{2}{*}{ No. } & \multirow[b]{2}{*}{ Activity } & \multirow[b]{2}{*}{ Sector } & \multicolumn{3}{|c|}{ Added Value } & \multicolumn{4}{|c|}{ Relation with } & \multicolumn{3}{|c|}{ Resources } \\
\hline & & & ARV & $\mathrm{ABV}$ & NAV & Quality & Cost & $\begin{array}{c}\text { Processing } \\
\text { cost }\end{array}$ & Cycle cost & People & Software & Hardware \\
\hline & & & & & & & & & & & & \\
\hline & & & & & & & & & & & & \\
\hline & & & & & & & & & & & & \\
\hline
\end{tabular}

Source: adapted from Müller (2003)

Finally, with the sub-process's analysis and the understanding of how each process interacts between the areas, the step 5, details, is reached. It is possible to have a discussion and find a critical process to propose improvements for the company. The critical process is chosen according to the definition of Rummler and Brache (1994). For them, a critical process is one that influences a competitive factor that the company wants to reinforce or expand. Still according to these authors, managers do not need sophisticated tools to identify critical processes, they just need a clear strategy.

Having as a strategy the use of MEIO, the prioritization criteria to find critical process was based on Müller (2003) work and validated with the management team of the company. To some items it was attribute a punctuation (e.g. impact on strategic objective, see section 4.3) and for other it was not necessary, since the processes involved were in very distinguished phases and the presence or absence of the criteria were very clear. The prioritization criteria were:

(a) Impact on Strategic Objectives;

(b) Potential results tangible in a short and medium term;

(c) Interactions with other Processes or Projects;

(d) Current Status of the Process (degree of problems/inoperability);

(e) Human and budgetary resources involved;

(f) Availability of the areas participating in the process

Since the application of some improvements are not immediate and require more execution time, it was the company's responsibility to continue with the process management vision and implement the proposed improvements.

\section{RESULTS}

\subsection{Overview}

With the application of the proposed methodology to the BPM aspects of Company $\mathrm{U}$, it was possible to create the business map, as shown in Figure 2, identifying the supplier market, inputs, company structure, outputs, buyer market, in addition to environmental influences, 
DOI: 10.14807/ijmp.v12i2.1331

competitors, and regulatory bodies. The studied company receives services from more than eight types of companies, with "medical offices" as the largest supplier, comprising $29 \%$ of this scenario.

Given that Company U offers services and products, its inputs are based on technical capacity, social and environmental responsibilities, and medical and hospital materials and medicines. The company is composed of six macro-processes, which are: (i) sale of products and services to consumers; (ii) receiving money from consumers and products and services from suppliers; (iii) making available the products and services received to consumers; (iv) receipt of accounts from consumers who have acquired the products/services; (v) auditing and verifying the accounts received and; (v) payment to service providers. The macro-processes were better described in the organization chart (Figure 3), leaving space to explain the structure of the company on the business map.

The main outputs are the health services needed by customers, exams, and medications. The buying market is puzzled with the supplying market because most service providers are also clients. As in the case of the hospital, it provides health services (supplier), and it is also a client that associates with Company $\mathrm{U}$ to have a broader range of treatments to offer people.

As for external influences, in addition to the regulatory bodies, such as the National Health Agency (ANS), which determines the laws and rules for the company to exist and operate, there are also environmental influences, as epidemics. One example is the outbreak of the virus COVID-19 in 2020 that significantly increased the demand for company services. The study company's competitors are other agencies that offer health insurance in the same region. The entire Business Map is detailed in Figure 2 and 3. 
DOI: 10.14807/ijmp.v12i2.1331

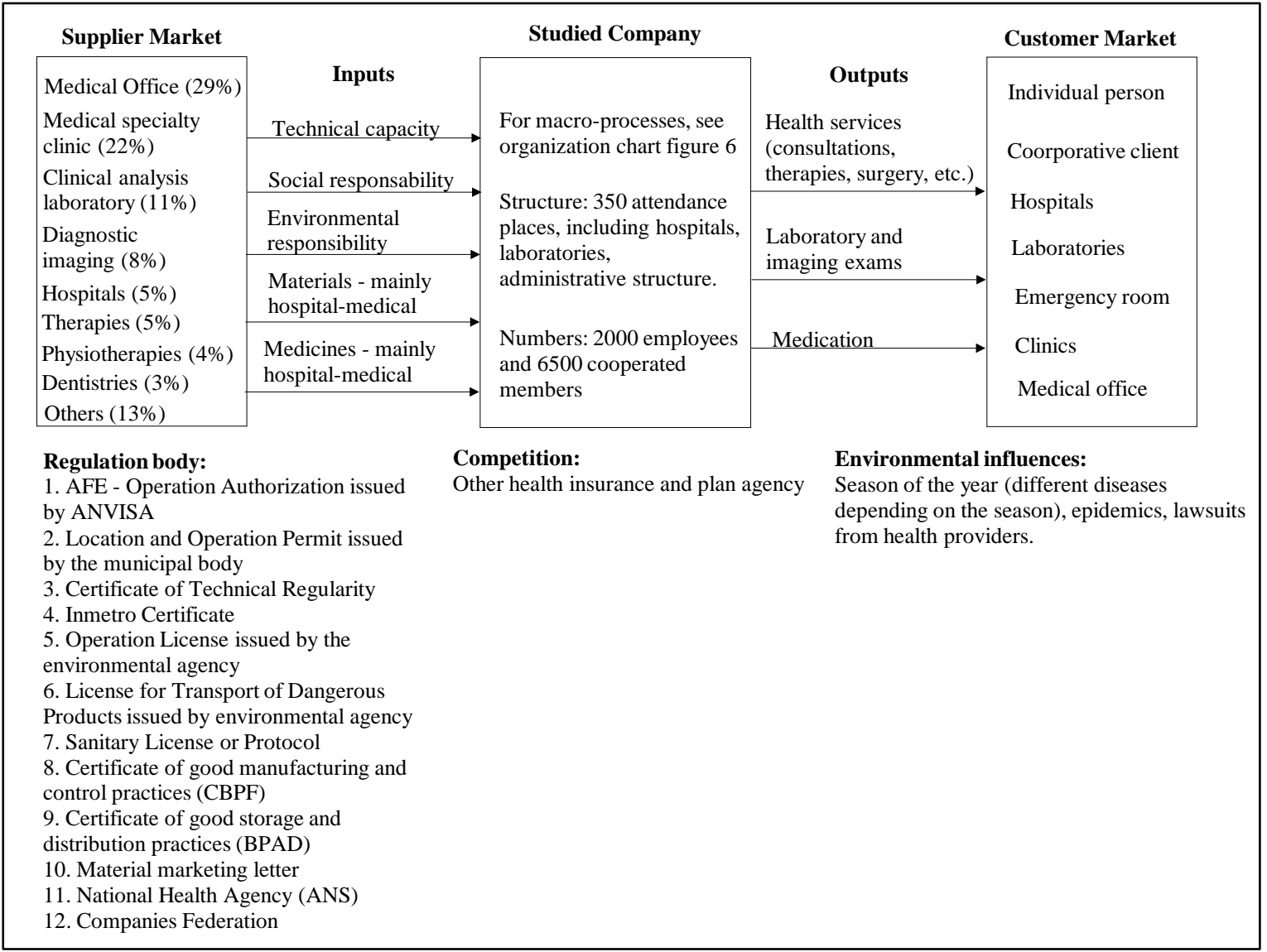

Figure 2:Company U Business Map

Source: Elaborated by the authors

The macro-processes flowchart was designed to complement the Business Map and to simplify the understanding of the company's configuration (Figure 6). Since Company U is a cooperative, physicians perform the role of suppliers and internal customers. Then, it was necessary to study all processes and actors to define the company's macro-processes due to the complexity of defining customers and providers.

This definition was done through the analysis of documents made available by the company. After they were analyzed, the macro-process that integrates all processes and actors were defined. In Figure 6, the mainline is the macro-processes and the secondary lines (lines above and below the mainline) are the agents (sectors) involved in each corresponding stage.

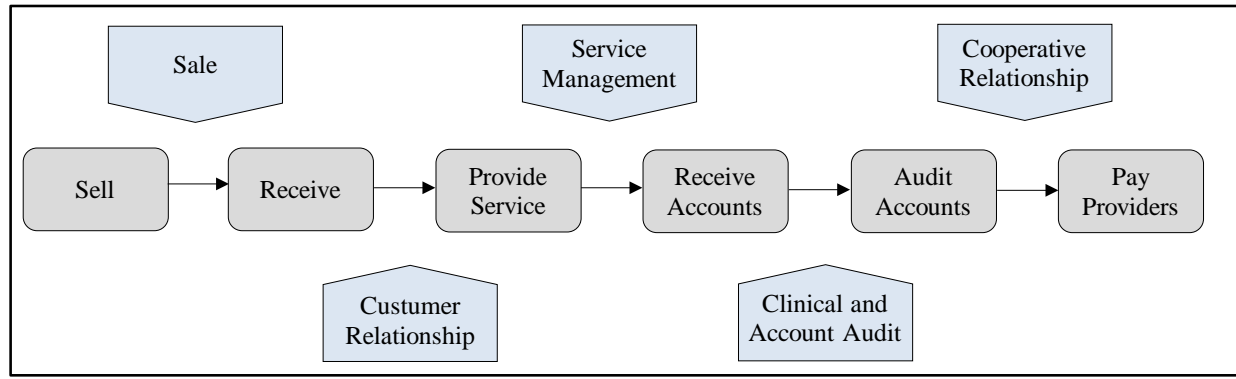

Figure 3: Company U macro-process.

Source: Elaborated by the authors 
According to Müller's (2003) recommendations, the organization's structure was graphically represented through the organization chart (Figure 4). It was assembled from the analysis of documents made available by the company and informal conversations with the strategic action team, which revealed that the company has a vertical strategic vision. Vertical structures mean predominance of hierarchy, in which the sectors with the most authority make the main decisions in view of the processes and subprocesses that are part of the organizational (Garcia \& Rufino, 2018).

In Company U, the General Meeting Board fulfills this role, passing the management decisions to the Administrative and Fiscal Councils and later to the Executive Board, Legal Counsel and Ombudsman, so on, until reaching the Super intendancies, as shown in Figure 4.

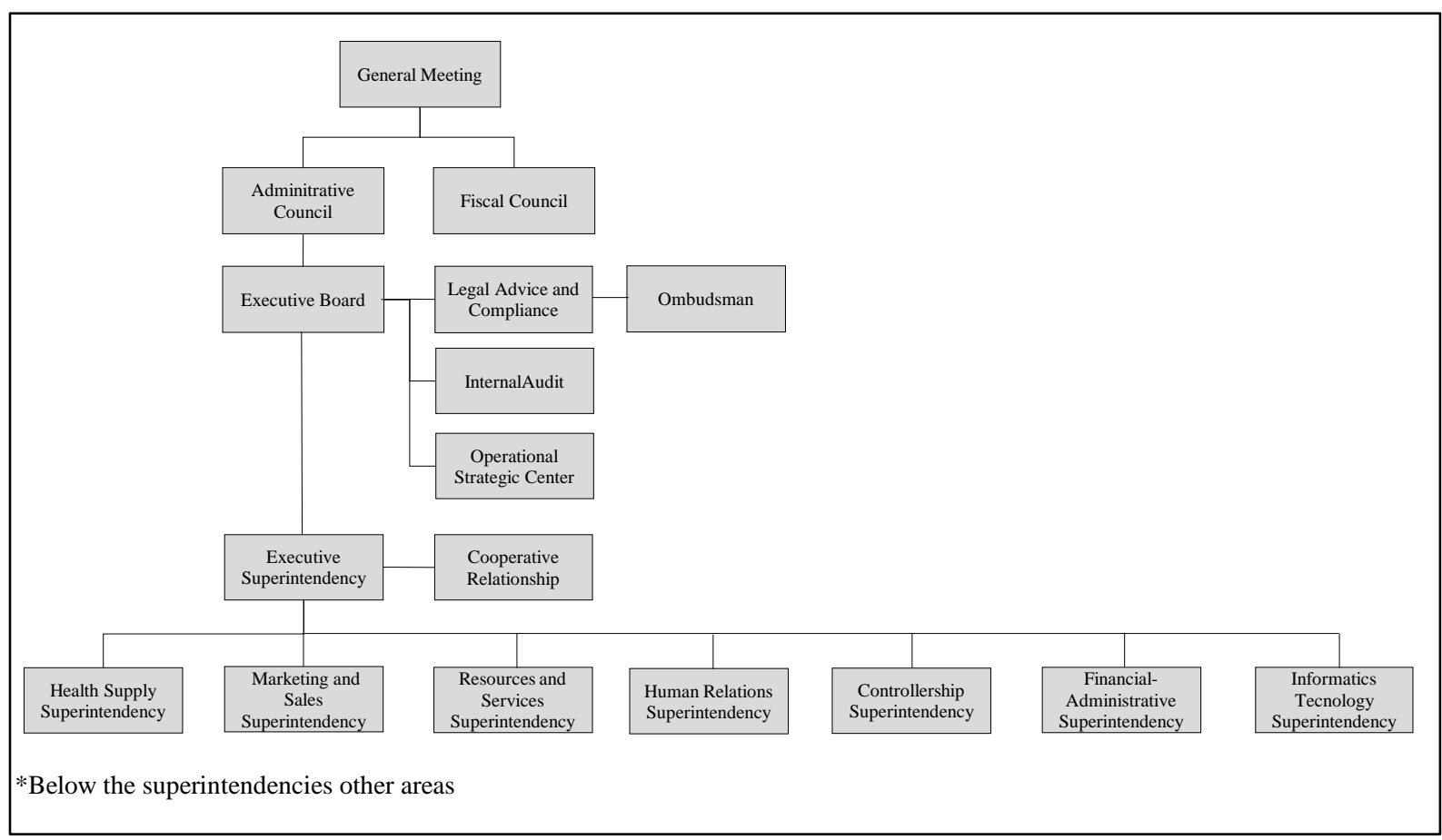

Figure 4: Company U Organization Chart

Source: Elaborated by the authors

\subsection{Process Hierarchy}

For the characterization of the main processes, the macro-process "payment of invoices from the provider" was chosen to be detailed, as explicated in section 3. This macro-process was divided into three key processes: (i) receiving accounts, (ii) auditing accounts and, (iii) paying audited accounts. These processes are related to the Health Supply Super intendancies (Costs Assistance management), Marketing and Sales (Marketing management), Controllership (Clinical Audit and Cost Audit management) and Financial Administrative (Finance management), being the last two more related to the processes under analysis. 
INDEPENDENT JOURNAL OF MANAGEMENT \& PRODUCTION (IJM\&P)

http://www.ijmp.jor.br

v. 12, n. 2, March-April 2021

ISSN: 2236-269X

DOI: 10.14807/ijmp.v12i2.1331

At this step, the characterization of each key process that composes this macro-process was made (Table 4). For each one was identified where it starts, what are the entries, what is developed, what are the exits, where it ends, who is the owner, who are the participants, what is the legislation relevant, what are the necessary skills, what are the process indicators, and software systems used. For example, the "auditing accounts” process begins in Cost Audit sector, with the receivement of invoice from providers.

There, they separate the invoices to be audited and deliver them to the responsible Auditors. Therefore, the "owner of the process" is the audit sector, but the financial sector also participates in the process. At this stage, the legislation followed is from the National Health Agency (ANS) and the necessary competency is knowledge to separate which invoices must be audited as procedural, which ones must be audit as cost and which ones should not proceed. The indicator used is the number of invoices received in the month. This entire process is carried out at Company U through the TOTVS ${ }^{\circledR}$ software system (Table 4).

Table 4: Characterization of the main processes of "payment of invoices from the provider" macro-process in Company U.

\begin{tabular}{|c|c|c|c|}
\hline \multicolumn{4}{|c|}{ Macro-process: payment of provider invoices } \\
\hline Processes & Receive accounts & Audit accounts & Pay Accounts \\
\hline Where it starts & Costs Audit & Costs Audit and Clinical Audit & Financial \\
\hline Entries & Providers invoice & Providers invoice & Providers invoice \\
\hline $\begin{array}{l}\text { What is } \\
\text { developed }\end{array}$ & Auditing costs & $\begin{array}{l}\text { Auditing both procedure (clinical audit) } \\
\text { and cost (inputs and procedures) }\end{array}$ & Providers payment \\
\hline $\begin{array}{c}\text { What is the } \\
\text { exit }\end{array}$ & Invoices to be audited & Audited invoices with and without gloss & Paid account \\
\hline Where it ends & Responsible Audit & Financial & Financial \\
\hline Owner & Audit sector & Audit sector & Audit sector \\
\hline Participants & Audit and finance & Audit and finance & Audit and finance \\
\hline Legislation & National Health Agency & National Health Agency & National Health Agency \\
\hline Skills & Knowledge & Medical knowledge and analysis & Knowledge \\
\hline Indicators & $\begin{array}{l}\text { Number of invoices } \\
\text { received in the month }\end{array}$ & Number of glosses & Number of accounts payed \\
\hline Systems & TOTVS® & TOTVS® & TOTVS® \\
\hline
\end{tabular}

Source: Elaborated by the authors.

\subsection{Team Definition}

After identifying the processes of the macro-process "payment of invoices from the provider," the Process vs. Sectors Matrix was develop with 9-3-1-0 scale to find the level of relation between process and sectors, with 9 being strong relation, 3 medium relation, 1 weak 
DOI: 10.14807/ijmp.v12i2.1331

relation and 0 not related (Figure 5). Besides, the Process vs. Sectors Matrix also presents the relationship with the strategic objectives of the company, which are (1) managing the client's health through integrated assistance practices, (2) simplifying operations and driving continuous improvements and (3) managing risks and promoting patient safety, also following the 9-3-1-0 scale. For each punctuation of the strategic objectives, a weight was assigned according to the emphasis given by the strategic planning team. For objective (1) the weight assigned was 4. For objectives (2) and (3) the weight was 1. This means that the process “receiving accounts" has little influence for objective 1 (1 multiplied by 4$)$, much influence for objective 2 ( 9 multiplied by 1 ) and little influence for objective 3 (1 multiplied by 1 ). Adding the points, the total is 14 for this process, in relation to the strategic objectives (Table 4). Thus, it can be noted that the macro-process "payment of invoices from the provider" are directly related to the objective of simplifying operations and driving continuous improvement.

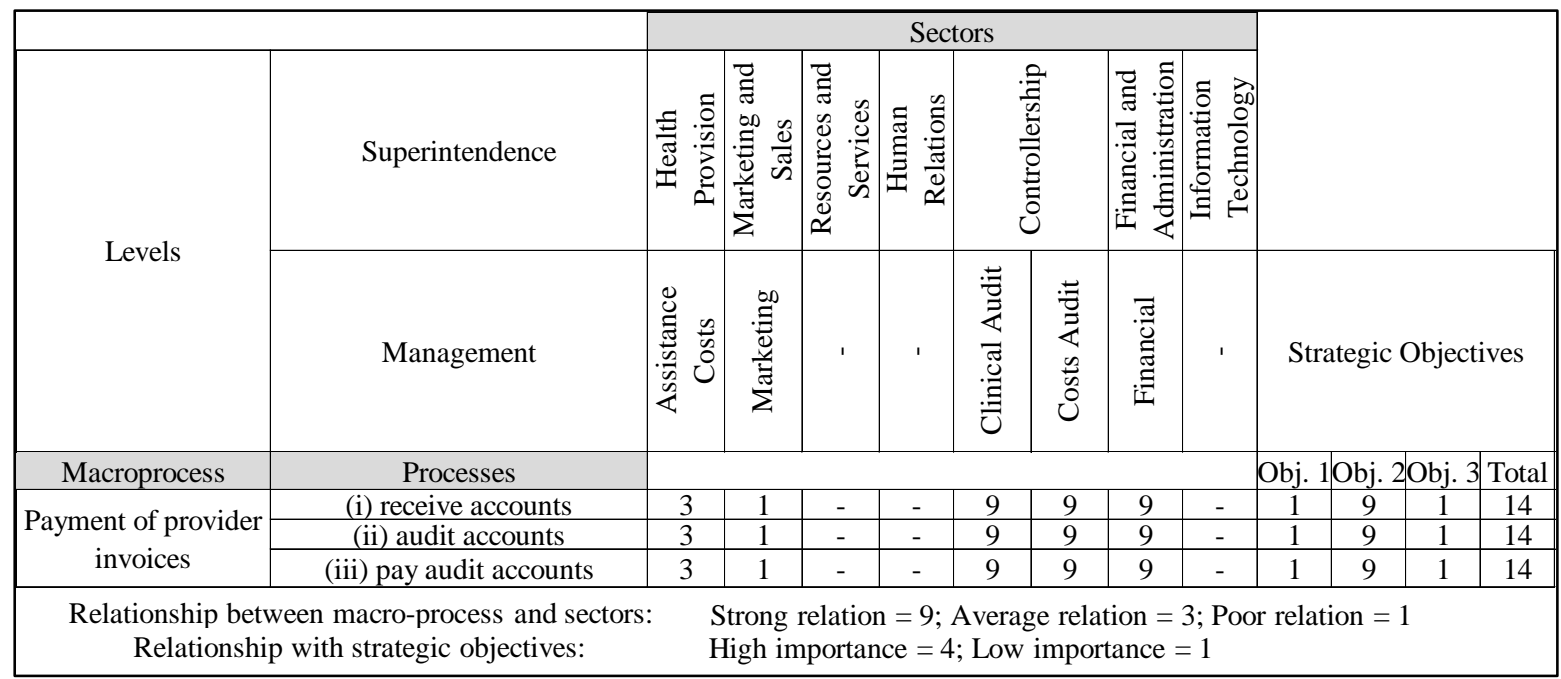

Figure 5: Process vs. Sectors Matrix for "payment of invoices from the provider” macroprocess in Company U.

Source: Elaborated by the authors

\subsection{Process Prioritization}

To the Process Prioritization step, before going to Value-Added analysis, it was decided to do the process mapping (Figure 6), prepared by BizAgi ${ }^{\circledR}$ tool. The main contribution of this visualization is to highlight which are the decision points and where they are in the process. Decision points reflect interactions between sectors and are critical moments in the process. This knowledge allows for more assertive actions, making it possible to reduce unnecessary steps in the process (why does the information pass through various sectors if the decision power is in sector $\mathrm{X}$ ?) and add value to the process. 
ISSN: 2236-269X

DOI: 10.14807/ijmp.v12i2.1331

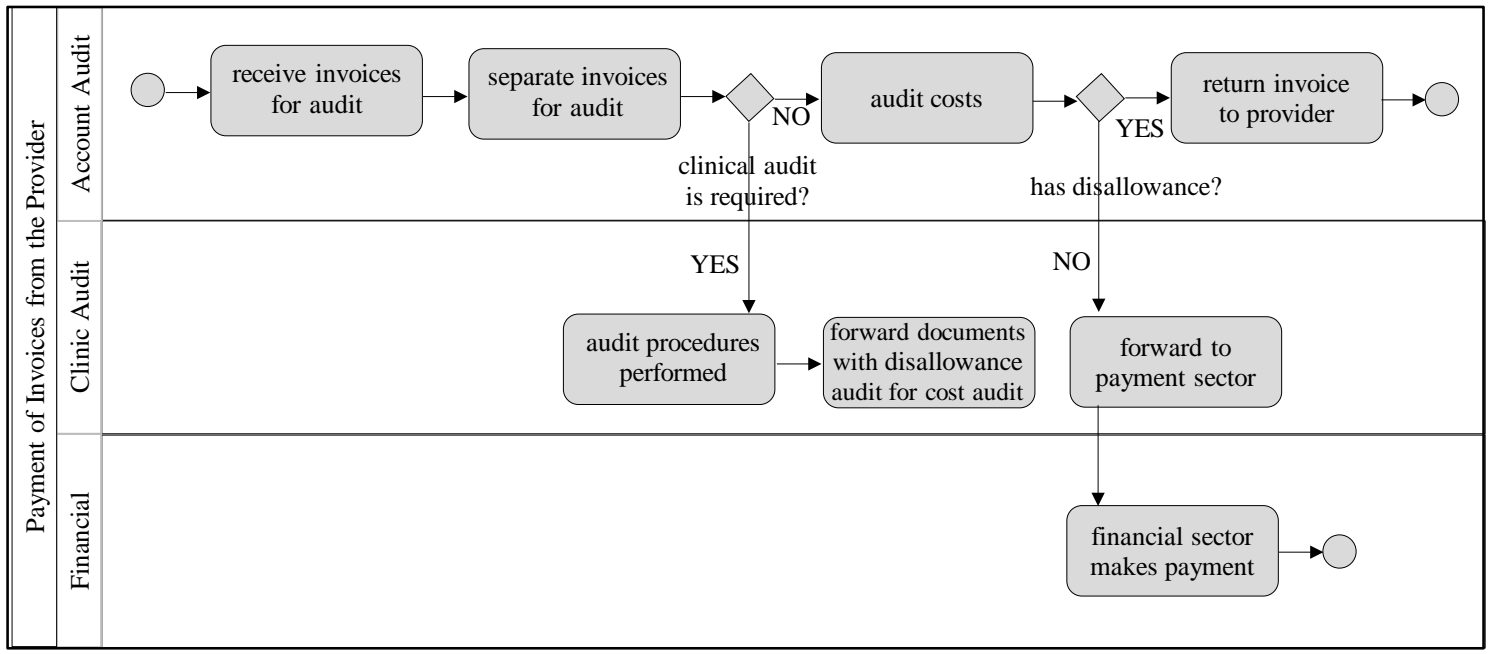

Figure 6: Flowchart of the macro-process "payment of invoices from the provider" in Company U.

Source: Elaborated by the authors

Thus, the Value-Added analysis was carried out, identifying which activities added real value (ARV), added business value (ABV), or did not add value (NAV). It was also determined the relationship between the process quality and cost using the 9-3-1-0 scale and the necessary resources. A large number of NAV activities have been identified. Of the nine sub-processes, seven have no added value, all with high-cost and low-quality ratio. When looking at resources, all sub-processes require personal effort, that is, they are little (if anything) automated activities (Figure 7). These are the main activities to invest in interventions.

\begin{tabular}{|c|c|c|c|c|c|c|c|c|c|c|c|c|c|c|}
\hline & & & \multicolumn{3}{|c|}{ Added Value } & \multicolumn{4}{|c|}{ Relation wih } & \multicolumn{3}{|c|}{ Resources } & \multicolumn{2}{|l|}{ Issues } \\
\hline$\dot{z}$ & 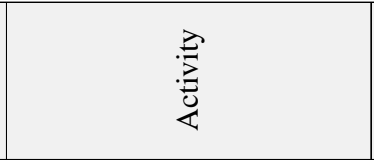 & 营 & 学 & 学 & 离 & 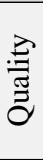 & ט̊ & 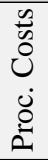 & 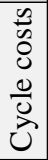 & 范 & 节 & 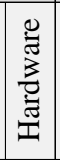 & 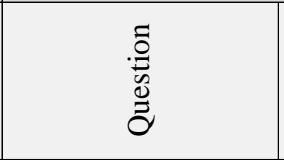 & 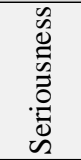 \\
\hline 1 & Receive invoices [1] & Cost Audit & - & - & $\mathrm{x}$ & 1 & 9 & 1 & 1 & $\mathrm{x}$ & - & - & \multirow{4}{*}{$\begin{array}{c}\text { Are there enough } \\
\text { rules in the software } \\
\text { to stop non- } \\
\text { compliance? }\end{array}$} & \multirow{4}{*}{ High } \\
\hline 2 & Separate invoices to audit & Cost Audit & - & - & $\mathrm{x}$ & 1 & 9 & 1 & 3 & $\mathrm{x}$ & - & - & & \\
\hline 3 & Send invoices to audit & Cost Audit & - & - & $\mathrm{x}$ & 1 & 9 & 1 & 1 & $\mathrm{x}$ & - & - & & \\
\hline 4 & Receive invoices [2] & Cost Audit & - & - & $\mathrm{x}$ & 1 & 9 & 1 & 1 & $\mathrm{x}$ & - & - & & \\
\hline 5 & Audit invoices & $\begin{array}{c}\text { Cost and } \\
\text { Clinical Audit } \\
\end{array}$ & - & $\mathrm{x}$ & - & 1 & 9 & 9 & 9 & $\mathrm{x}$ & $\mathrm{x}$ & $\mathrm{x}$ & \multirow{5}{*}{$\begin{array}{l}\text { Are there automation } \\
\text { of processes to be } \\
\text { done? Is the process } \\
\text { mature for that? } \\
\text { What are the process } \\
\text { errors that need to be } \\
\text { eliminated before } \\
\text { being automated? }\end{array}$} & \multirow{5}{*}{ High } \\
\hline 6 & $\begin{array}{c}\text { Return invoice with } \\
\text { disallowance to the provider }\end{array}$ & Cost Audit & - & - & $\mathrm{x}$ & 1 & 9 & 1 & 1 & $\mathrm{x}$ & - & - & & \\
\hline 7 & $\begin{array}{c}\text { Forward invoice withou } \\
\text { disallowance for payment }\end{array}$ & Cost Audit & - & - & $\mathrm{x}$ & 1 & 9 & 1 & 1 & $\mathrm{x}$ & - & - & & \\
\hline 8 & $\begin{array}{c}\text { Receive audites accounts to } \\
\text { payment }\end{array}$ & Financial & - & - & $\mathrm{x}$ & 1 & 9 & 1 & 1 & $\mathrm{x}$ & - & - & & \\
\hline 9 & Pay audit accounts & Financial & $\mathrm{x}$ & - & - & 1 & 9 & 3 & 3 & $\mathrm{x}$ & $\mathrm{x}$ & $\mathrm{x}$ & & \\
\hline
\end{tabular}

Figure 7: Subprocess analysis

Source: Elaborated by the authors

\subsection{Details}


INDEPENDENT JOURNAL OF MANAGEMENT \& PRODUCTION (IJM\&P)

http://www.ijmp.jor.br

v. 12, n. 2, March-April 2021

ISSN: 2236-269X

DOI: 10.14807/ijmp.v12i2.1331

At this step, based on the analyses done so far, it was possible to have a discussion with the management team of the company and propose improvements for the critical process (see Table 5, section 5). As mentioned, from the nine processes, seven was indicated for enhance its performance, or even eliminated. Thus, besides prioritization criteria to find critical process presented in section 3, it was decided to work with all NAV processes of "payment of invoices from providers”, due to the Company's capacity to absolve this challenge. Some questions raised for the detailed analyses involved the capacity of the company to support automation (are there enough rules in the software to stop non-compliance? Is the processes mature for automation? What are the process errors that need to be eliminated before being automated?). It is a starting point to have a BPM approach consolidated.

\section{DISCUSSION}

Based on extensive analysis and understanding of the organization's structure and subprocesses, it was possible to identify some points for improvement. First, there is a large number of activities with no added value, associated with high costs, low quality, and excessive personal demand. These are the leading candidates to be eliminated. They were separated into two groups: activities that take place before "audit invoices" (receive invoices, separation of invoices to audit, sending invoices for auditing, receive invoices by the audit) and activities that happen after the audit of invoices (return invoice with disallowance to the provider, forward invoice without disallowance for payment, receive audited accounts for payment).

The activity "invoice audit" was chosen as a divisor because it is the first activity in the process that has added value. Another issue about the NAV activities is that there is excessive manual control. In discussion with the management team, it was understood that this occurs mainly due to the lack of a system with more efficient rules and lack of standardization information. Hence the flow is slow, with waiting in the procedures and rework, making the process costly and painful. Thus, information and knowledge end up more centered on people than on processes. Schmidt and Nurcan (2008) reported that is possible to enhances business processes by improving the exchange of knowledge and information. The elimination of NAV activities helps to speed up decisions and better integrates the needs of all stakeholders in a more complete way.

Literature approaching BPM usually brings as a solution innovation in technology such as XML, Web services, component-based development, and message-oriented middleware (Verner, 2004). Paschek et al. (2016) combines methods and tools of BPM to contribute positively to the Enterprise Information System. This allows companies to act flexible to adapt 
or implement enterprise processes, which makes the added value evident. Also, softwares that supports interactions of people can be used to overcome deficiencies of classic BPM approaches, which seen to be the case in Company U (Schmidt \& Nurcan, 2008). For that reason, most suggestions for improvements includes a technology-oriented approach.

The first topic focus on eliminate NAV activities. All NAV activities that happen before "audit invoices" should become part of that activity, while all that happen after "audit invoices" should become part of the "pay audit accounts." However, the mere transfer of these activities is not enough, they need to be reduced. Suggestions for improvements include creating rules engine to validate the procedures to be launched according to coverage and shortage of the beneficiary's plan and also according to the provider contract.

This measure eliminates the need for activity number 2 (separation of invoices to audit). To remove activities 1 and 3, the authors of the present research suggested to digitize and automate the processes of receiving and sending invoices. Considering they would be selected earlier, audits would go directly to the responsible audit sector, this means cost audit or clinical audit. In this way, the employee is released to do activities that have added value, making Company U more productive.

The second group of NAV activities, which comes after the "audit invoices," comprises invoices with disallowance that must be returned to the provider. This happens when there is an unknown procedure or a combination of unusual procedures (or medication) used. The audit is then sent to the clinical examination, formed by nurses and doctors who can decide if the account is correct. The invoice with disallowance returns to the audit to pay the account (or is sent to the provider, if not approved).

Thus, for this group of activities, the suggestion for improvement is to receive separately what is procedural and what is cost. Then, follow the idea to digitalize and automate the sending and receiving processes. Finally, this process would be reduced to just two activities: "audit invoices" and "pay audit accounts." Improvement proposals for each activity are presented in Table 5.

Table 5: Proposal for improvements by activity of the analyzed process

\begin{tabular}{|l|l|l|l|}
\hline No. & \multicolumn{1}{|c|}{ Activities } & \multicolumn{1}{|c|}{ Sector } & \multicolumn{1}{c|}{ Improvement Proposal } \\
\hline 1 & Receive invoices [1] & Cost Audit & $\begin{array}{l}\text { Create rules engine to validate the procedures to be } \\
\text { launched according to coverage and shortage of the } \\
\text { beneficiary's plan. Also, according to the contract with } \\
\text { the provider; } \\
\text { Digitalization and automatization }\end{array}$ \\
\hline 2 & Separate invoices to audit & Cost Audit & Receive separately what is procedural and what is cost \\
\hline 3 & Send invoices to audit & Cost Audit & Digitalization and automatization \\
\hline
\end{tabular}


INDEPENDENT JOURNAL OF MANAGEMENT \& PRODUCTION (IJM\&P)

http://www.ijmp.jor.br

v. 12, n. 2, March-April 2021

ISSN: 2236-269X

DOI: 10.14807/ijmp.v12i2.1331

\begin{tabular}{|c|c|c|c|}
\hline 4 & Receive invoices [2] & Cost Audit & Digitalization and automatization \\
\hline 5 & Audit invoices & $\begin{array}{l}\text { Cost and } \\
\text { Clinical Audit }\end{array}$ & - \\
\hline 6 & $\begin{array}{l}\text { Return invoice with } \\
\text { disallowance to the } \\
\text { provider }\end{array}$ & Cost Audit & $\begin{array}{l}\text { Receive separately what is procedural and what is cost } \\
\text { Digitalization and automatization }\end{array}$ \\
\hline 7 & $\begin{array}{l}\text { Forward invoice without } \\
\text { disallowance for payment }\end{array}$ & Cost Audit & Digitalization and automatization \\
\hline 8 & $\begin{array}{l}\text { Receive audits accounts } \\
\text { to payment }\end{array}$ & Financial & Digitalization and automatization \\
\hline 9 & Pay audit accounts & Financial & - \\
\hline
\end{tabular}

Source: Elaborated by the authors.

Ultimately, the improvements proposed seeks to achieve some advantages mentioned in the literature review: shorter response time, improve internal communication, reduce bureaucracy, increase reliability of operations, increase employees satisfaction and align strategic objectives with the objectives of processes (Zairi, 1997; Detoro \& Mccabe, 1997; Harrington, 1993). This agrees with Company U need to streamline business operations, consolidate a clear and well-defined strategy to management processes, and save costs. Thereby reflecting the fact that the process is the basic unit of business value within an organization (Li \& Sum; 2006).

\section{CONCLUSION}

BPM is a systemic method of managing a company's processes. There are several approaches to applying BPM, however, they seem to focus on only some aspects of the company (such as financial and economic) while neglecting others (such as customer retention and employee engagement). These isolated models make significant contributions but fail to provide a model that covers all needs of the company.

Thus, the Strategy, Indicators and Operations Model (MEIO), developed by Müller (2003), compiles the advantages of each of the isolated models, creating a way to complement the weaknesses of one approach with the strengths of another. The objective of this work is to provide a step-by-step BPM aspects of MEIO in a practical case. Thus, managers can count on a process analysis guide and suggestions for improvements, as well to redesign their processes. BPM aspects of MEIO was applied to a reference health service company.

After understanding the company's structural architecture and general issues, the critical processes "payment of invoices to providers" was chosen to identify its processes and activities, and then to propose improvements. This process was chosen because it fulfilled the prioritization criteria proposed by the authors and due to its importance for the company under study. However, this is a limitation of this study. 
DOI: 10.14807/ijmp.v12i2.1331

It would be adequate to implement MEIO in all processes. Yet, this decision was made because in large companies the large number of processes makes it impossible to study all of them in a plausible period. In addition, it is recommended that interventions are carried out in parts, so the improvements achieved are more easily monitored and maintained. To futurity continuous the application of MEIO, from a mapped and analyzed process, a next step would be the revision of the indicators associated with this process, as well as the eventual reassessment of the contribution of the process to the strategic objectives of the organization.

This study provided a perception of the importance of a clear and well-defined strategy that allows the management of processes in companies. The lack of visualization of the relations between the sectors and the high demand for manual activities without added value, did not allow the process to be efficient. The most relevant results are summarized in eliminating activities that do not add value, coupling those necessary to other activities that add value.

In order to do that, the suggestions for improvements are: (i) create rules engine to validate the procedures to be launched according to coverage, shortage, and contract; (ii) receive separately procedural and cost audits and; (iii) digitalize and automatize repetitive and manual activities (as receiving and sending audits). The aim is to stimulate the culture of process management within the company, taking as an opportunity for future studies the analysis of other key processes, as well as the application of the steps of MEIO in different sectors and processes.

\section{REFERENCES}

Aghabaghery, R., Golpayegani, A. H., \& Esmaeili, L. (2020). A new method for organizational process model discovery through the analysis of workflows and data exchange networks. Social Network Analysis and Mining, 10(1), 12.

Albuquerque, A., \& Rocha, P. (2006). Sincronismo organizacional: como alinhar a estratégia, os processos e as pessoas. São Paulo: Saraiva, 166.

Antonucci, Y., \& Goeke R. (2011). Identification of appropriate responsibilities and positions for business process management success - Seeking a valid and reliable framework. Business Process Management Journal, 17(1), 127-146.

Association Of Business Process Management (ABPM) (2013). Guia para o

Gerenciamento de Processos de Negócios (CBOOK BPM). Corpo Comum de Conhecimento.

Baldam, R., Valle, R., Pereira, H., Hilst, S., Abreu, M., \& Sobral, V. (2009). Gerenciamento de processo de negócios: BPM - Business Process Management. 2.ed. São Paulo: Érica.

Burlton, T. (2001). Business Process management: profiting from process. Indianapolis: Sams), 398 
Cho, H. (2014). Determinants and effects of logistics costs in container ports: the transaction cost economics perspective. The Asian Journal of Shipping and Logistics, 30(2), 193-215.

De Sordi, J. (2012). Gestão por processos: uma abordagem da moderna administração. 3.ed., rev. e atual. São Paulo: Saraiva.

Detoro, I., \& Mccabe, T. (1997). How to stay flexible and elude fads. Quality Progress, 30(3), 55-60.

Dumas, M., La Rosa, J. Mendling, H., \& Reijers. (2013). Fundamentals of business process management, 1 . Springer.

Edvinsson, L; \& Malone, M. (1998). Capital intelectual: descobrindo o valor real de usa empresa pela identificação de seus valores internos. São Paulo: Makron Books), 230.

Elzinga, D. J., Horak, T., Lee, C. Y., \& Bruner, C. (1995). Business Process Management: Survey and Methodology. IEEE Transactions On Engineering Management, 42(2), 119128.

Garcia, B. D., \& Rufino, E. (2018). Análise da Viabilidade Financeira da Integração

Vertical Aplicada aos Jogos de Empresas. Revista Lagos, 9(2).

Gerhardt, T. E., \& Silveira, D. T. (2009). Métodos de Pesquisa. Coordenado pela

Universidade Aberta do Brasil - UAB/UFRGS e SEAD/UFRGS. Porto Alegre: Editora da

UFRGS. Available: http://www.ufrgs.br/cursopgdr/downloadsSerie/derad005.pdf. Access: 04/04/2020.

Gil, C. (2008). Como elaborar projetos de pesquisa. 4. ed. São Paulo: Atlas.

Guha, S., \& Kettinger, W. J. (1993). Business process reengineering. Information Systems Management, 10(3), 13-22.

Hansen, P. (1995). Indicadores de desempenho gerencial. Apostila (Projeto Gestão Empresarial e Qualidade) - Serviço Nacional da Indústria (SENAI), Federação das Indústrias do estado do Rio Grande do Sul (FIERGS), Porto Alegre.

Harrington, H. J. (1993). Aperfeiçoando processos empresariais. São Paulo: Makron Books), 368.

Iritani, D. R., Morioka, S. N., Carvalho, M. M. De, \& Ometto, A. R. (2015). Análise sobre os conceitos e práticas de Gestão por Processos: revisão sistemática e bibliometria. Gestão \& Produção, 22, 164-180.

Jesus, L., \& Macieira, A. (2014). Repensando a gestão por meio de processos. Editora Algo Mais. Rio de Janeiro.

Kanellis, P., Lycett, M., \& Paul, R. (1999). Evaluating business information systems fit: From concept to practical application. European Journal of Information Systems, 8(1), $65-76$.

Lee, R. G., \& Dale, B. G. (1998). Business process management: a review and evaluation. Business Process Management Journal, 4(3), 214-225.

Li, Z., J., \& Sum, W. (2006). BPEL-Unit: Junit for BPEL Process. International Conference Service-Computing Oriented, Chicago, USA. p. 415-426.

Markey, R., \& Ott, J.(2007). Winning new customers using loyalty-based segmentation. Strategy \& Leadership, 35(3), 32-37. 
Mccormack, K., \& Johnson, W. (2001). Business process orientation: Gaining the Ebusiness competitive advantage. Delray Beach: St. Lucie Press.

Mccormack, K., Willems, J., Van Den Bergh, J., Deschoolmeester, D., Willaert, P., \& Indihar S. M. (in press). A Global investigation of key turning points in business process maturity. Business Process Management Journal.

Müller, C. J. (2003). Modelo de gestão integrando planejamento estratégico, sistemas de avaliação de desempenho e gerenciamento de processos (MEIO - Modelo de estratégia, indicadores e operações). Tese. (Doutorado em Engenharia de Produção). Porto Alegre: UFRGS. Available: https://lume.ufrgs.br/handle/10183/3463. Access: 04/04/2020

Murlick., J. (2014). Fatores Críticos de Implementação da metodologia Business Process Management (BPM): Estudo de Caso no Sistema de Crédito Cooperativo Sicredi. Dissertação. (Mestrado em Engenharia de Produção). PortoAlegre: UFRGS. Available: https://lume.ufrgs.br/handle/10183/109015. Access: 04/04/2020

Oliveira, S., \& Almeida Neto, M. (2013). Análise e modelagem de processos. In: Valle, R., Oliveira, S. B. de. Análise e modelagem de processos de negócio. São Paulo: Atlas, 37-51.

Paschek, D., Rennung, F., Trusculescu, A., \& Draghici, A. (2016). Corporate Development with Agile Business Process Modeling as a key Success Factor. Procedia Computer Science, 100, 1168-1175.

Porter, M. (1990). Vantagem competitiva: Criando e sustentando um desempenho superior. Rio de Janeiro: Campus, 530.

Rafaeli, L., \& Muller, C. (2007). Structuring an AHP based consolidated performance index. Gestão \& Produção, 14(2).

Ranganathan, C., \& Dhaliwal, J. S. (2001). A survey of business process reengineering practices in Singapore. Information \& Management, 39(2), 125-134.

Reichheld, F. (2003). The One Number You Need to Grow. Harverd Business Review. v. 81, n 12), 46-54. Available: https://hbr.org/2003/12/the-one-number-you-need-to-grow. Access: 04/04/2020

Rummler, G. A., \& Brache, A. P. (1994). Melhores desempenhos das empresas. 2. ed. São Paulo: Makron Books, 284.

Schmidt R., \& Nurcan S. (2009) BPM and Social Software. In: Ardagna D., Mecella M., Yang J. (eds) Business Process Management Workshops. BPM 2008. Lecture Notes in Business Information Processing, 17. Springer, Berlin, Heidelberg.

Schmiedel, T., Recker, J., \& Vom Brocke, J. (2020). The relation between BPM culture, BPM methods, and process performance: evidence from quantitative field studies. Information \& Management, 57(2), 103-175.

Sellitto, M., \& Walter, C. (2006). Performance assessment of a manufacture firm of electronic equipment in terms of competitive priorities. Produção, 16 (1).

Simpson, M., Kondouli, D., \& Wai, P. H. (1999). From benchmarking to business process re-engineering: a case study. Total Quality Management, London, 10(4-5), S717-724.

Skerlavaj, M., Indihar Stemberger, M., Skrinjar, R., \& Dimovski, V. (2007). Organizational learning culture-The missing link between business process change and organizational performance. International Journal of Production Economics, 106(2), 346-367. 
Stewart, T. (1997). Capital intelectual: a nova vantagem competitiva das empresas. Rio de Janeiro: Campus), 262.

Strnadl, C. F. (2006). Aligning business and it: The process-driven architecture model. Information Systems Management, 23(4), 67-77.

Torres, I. S., \&Ribeiro, J. L. D. (2015). Aplicação da Metodologia BPM em uma IFES: Proposição de um Modelo Estendido. Dissertação. (Mestrado em Engenharia de Produção). Porto Alegre: UFRGS. Available: https://lume.ufrgs.br/handle/10183/118886. Access: 04/04/2020

Trætteberg H., \& Krogstie J. (2008) Enhancing the Usability of BPM-Solutions by Combining Process and User-Interface Modelling. In: Stirna J., Persson A. (eds) The Practice of Enterprise Modeling. PoEM 2008. Lecture Notes in Business Information Processing, vol 15. Springer, Berlin, Heidelberg.

Verner, L. (2004). BPM: the promise and the challenge. Association for Computer Machinery, 2(1), 83-91.

Vom Brock, J., \& Rosemann, M. (2013). (Eds.), Handbook on Business Process Management 2. Heidelberg et al.: Springer, 93-114.

Young, J. (2012). Social capital and trust for a web environment. Personal Knowledge Capital. WoodHead Publishing (Ed.) United States: Oxford, 81-90

Zairi, M. (1997). Business process management: A boundary less approach to modern competitiveness. Business Process Management Journal, 3(1), 64-80. 